\title{
Hrvatska i Bizant u 10. stoljeću
}

\author{
Izvorni znanstveni rad \\ Original scientific paper
}

UDK 94(497.5:495.02)“08/10“

U radu se analiziraju odnosi Hrvata i Bizanta od kraja 9. do početka 11. st. Objašnjava se širenje uporabe hrvatskog imena izvan granica Hrvatske, razlozi zašto je Bizant prepustio dalmatinske gradove na upravu hrvatskim vladarima i zašto je Stjepanu I. Držislavu poslao krunu.

Ključne riječi: Hrvati, Bizant, Dalmacija, Bugari, Simeon, Konstantin VII., Ivan I. Cimisk, Tomislav, Stjepan I. Držislav, hrvatski vladari

$\mathrm{R}^{2}$ azmatrajući odnose Bizanta i Hrvatske u 10. stoljeću, moramo pažnju usmjeriti na dva problema. Prvi je položaj Hrvatske unutar bizantskog commonwealtha, a drugi, s njim usko povezan, jest način na koji su se bizantski i drugi pisci, a ponajprije Konstantin Porfirogenet, odnosili prema hrvatskoj eliti. Mogli bismo ovu analizu započeti s potonjim.

Prije 10. st. postoje samo dva sigurna spomena hrvatskog imena, oba s područja same Hrvatske. Prvi je u Trpimirovoj darovnici, u kojoj se vladar naziva dux Chroatorum, dok je drugi na Branimirovom natpisu iz Šopota kod Benkovca, na kojem je zabilježena ista vladarska titular (Stipišić - Šamšalović 1967: 3-8; Budak 1994: 75-76). ${ }^{1}$ Tome bismo mogli pribrojiti još dva fragmenta kamenih natpisa na kojima su se vjerojatno spominjala imena velikodostojnika nedavno nastale kneževine Hrvata (Delonga 1996: 52 i 194). U svakom slučaju, svi nam oni svjedoče da se hrvatsko ime koristilo unutar Hrvatske, ali ne i izvan njezinih granica, jer se svi ostali sačuvani izvori 9. stoljeća, bez obzira na to jesu li nastali u Italiji, Bizantu ili franačkom svijetu, opisujući stanovništvo nekadašnje Dalmacije koriste samo općim imenom Slavena ili, ako su određeniji, onda Dalmatinaca (Budak 2008: 223241). ${ }^{2}$ Ti se odnosi mijenjaju tijekom prve polovice 10. st., kada se hrvatsko ime pojavljuje u tri izvora koji su nastali izvan Hrvatske. Mletački kroničar Ivan Đakon, koji se kada opisuje događaje na istočnoj obali Jadrana u 9. st., koristi samo imenom Slavena (i u jednom slučaju Neretvana), pišući o zbivanjima 912. godine spominje Chroatorum fines. Usprkos tome što se tako konzekventno izbjegavao koristiti hrvatskim imenom za opisivanje prethodnih događaja, ipak moramo voditi računa o tome da on piše oko 1000. godine i da je njegovo shvaćanje uloge Hrvata možda posljedica njihove prepoznatljivosti u njegovo vrijeme, a ne početkom 10. st. Ipak, mislim da je izraz Chroatorum fines doista jedan od znakova jačanja

Neki su autori predložili ranije datiranje Trpimirove darovnice, koje nije općeprihvaćeno (Margetić 1993: 47-51; 2002: 8-9; Matijević Sokol 2010: 12-14. Za Branimirov natpis: Delonga 1996: 166-167.

2 O uporabi etničkih imena u to doba i Fine 2006. Knjiga sadrži dobar pregled izvora, ali je njihova interpretacija, nažalost, ideološki jednostrana. Fine smatra Slavene prirodnom pojavom, dok je hrvatsko ime za njega samo geografska kategorija ili znak pripadnosti nekog pojedinca vojsci hrvatskog vladara. Objavio sam dvije recenzije ove knjige: u časopisu Speculum 86/1 (January 2011): 187-8 i Budak 2009. Najnoviji prilog diskusiji: Dzino 2009; 2010. 
hrvatske elite i njezinog ugleda i izvan hrvatskih granica. Ivan Đakon nastavit će spominjati Hrvate i kasnije, kada će opisivati pohod dužda Petra Orseola na Dalmaciju i Biograd (Budak 2008: 234-236).

Drugi izvor koji spominje hrvatsko ime u vezi je sa splitskim crkvenim saborima 925. i 928. Riječ je o djelu Historia salonitana maior, koje je šesnaestostoljetna prerada djela Tome Arhiđakona. Usprkos dvojbama koje još uvijek izaziva autentičnost pojedinih nadopuna uključenih u to djelo, većina se povjesničara slaže da su papinska pisma i ostali tekstovi vezani uz splitske crkvene sabore autentični (Klaić 1967 - dalje HSM). ${ }^{3}$ Historia salonitana maior zna za Tomislava koji je bio rex Chroatorum, a spominje hrvatsko ime još nekoliko puta (HSM, Indices; Budak 2008: 237).

Možda bismo i ovaj izvor, kao i Ivana Đakona, mogli odbaciti kao nevjerodostojne za dokumentiranje rastuće moći hrvatske elite početkom 10. st. kada ne bismo imali treći koji se nikako ne može dovesti u sumnju. Riječ je, dakako, o Konstantinu Porfirogenetu. U svojem glavnom djelu, De administrando imperio, car je posvetio veliku pažnju prvom opisu zemlje koja se nazivala Hrvatskom i ljudima koji su u njoj živjeli. U više je navrata spomenuo Hrvate i u drugim poglavljima u kojima je opisivao pojedine sklavinije duž istočnojadranske obale i objašnjavao sudbinu koja je zadesila rimsku Dalmaciju (Moravcsik - Jenkins 1967: 122-131 i 134-165 dalje: DAI). Teško je zamisliti da bi sva tri međusobno neovisna izvora, opisujući gotovo istovremenu situaciju (912. - oko 950.), slučajno spominjala Hrvate čije je ime samo nekoliko desetljeća prije bilo nepoznato i u Rimu, i u Veneciji. U suvremenoj historiografiji već je izraženo mišljenje da pojam „Hrvati“ nije označavao etničku zajednicu, već vodeću skupinu koja je činila elitu unutar stanovništva nekadašnje rimske Dalmacije. ${ }^{4}$ Uspon ove elite bio je usko vezan uz karolinške utjecaje u provinciji tijekom prvih desetljeća 9. st., ali nije bio prepoznat izvan granica područja što ga je ova skupina imala u svojoj vlasti (Budak 1997; Ančić 1997; Dzino 2010: 177-190).

Postoje li neka prihvatljiva tumačenja za ovo rastuće zanimanje za Hrvatsku, kao i za njezinu sve veću važnost u međunarodnim odnosima u prvoj polovici 10. st.? Mislim da se ključ odgovora može naći u bizantsko-bugarskom sukobu i ulozi koju je Hrvatska u tome imala (Šišić 1925: 422-429; Zlatarski 1927: 477 passim; Ćirković 2004: 17-20; Ostrogorski 2006: 151-156).

lako je Hrvatska od vremena Aachenskog mira 812. godine pripadala karolinškoj sferi utjecaja, položaj dalmatinskih gradova omogućavao je Bizantu da zadrži određeni utjecaj u regiji (Goldstein 1992; 1998: 7-14). ${ }^{5}$ Bez želje da ulazim u raspravu o tom kada je Dalmacija proglašena temom, htio bih naglasiti odluku Bazilija I. da njegovi dalmatinski podložnici danak koji su dotad davali strategu ubuduće plaćaju hrvatskom vladaru i, u slučaju Dubrovnika, vladarima Zahumlja i Travunije. Strateg je zadržao pravo na simbolično davanje kao znak da

\footnotetext{
U najnovije vrijeme, s obzirom na pitanje autentičnosti izvora umetnutih u HSM: Prozorov 2006, napose 229; 2012. O pitanju umetnutih izvora i njihove tradicije Budak 2013.

4 Ideja da su Hrvati bili vodeća skupina među dalmatinskim Slavenima nije nova. Iznijeli su ju već Vjekoslav Klaić i Ljudmil Hauptmann. Po njima su, međutim, Hrvati bili etnička skupina koja se nametnula dalmatinskim Slavenima, dok su u novije vrijeme Otto Kronsteiner i Walter Pohl, kojima sam se i sam pridružio, iznijeli tezu da je hrvatsko ime označavalo ratnički sloj na rubovima Avarskog kaganata, a ne etničku zajednicu. Vidi: Kronsteiner 1978; Pohl 1988: 261-288; Budak 1994: 67-70. U svojem najnovijem radu na tu temu nastojao sam izraziti opreznije mišljenje o tom pitanju, ističući da je jedino čvrsto uporište u raspravi o najranijoj povijesti Hrvata pojava hrvatskog imena sredinom 9. st. Vidi Budak 2008: 239-241. Najnoviji i detaljan pregled problematike u Dzino 2010, sa zaključcima na str. 182 i 208-10, gdje autor s pravom kao nevažno odbacuje pitanje jesu li se Hrvati doselili u Dalmaciju ili su pripadali domaćoj populaciji.

5 Dok Goldstein zastupa mišljenje o jačim bizantskim utjecajima u Hrvatskoj/Dalmaciji, Ančić 1998 je skloniji umanjivanju njihove važnosti. Nedavno je Nikola Jakšić iznio uvjerljive argumente u prilog bizantskoj nazočnosti u Dalmaciji u 8. st.: Jakšić 2008.
} 
gradovi i dalje prihvaćaju carsku i njegovu vlast. ${ }^{6}$ Ova je odluka po svoj prilici bila posljedica obnovljene prisutnosti bizantskog brodovlja u Jadranu, kao i pokušaja Konstantinopola da na hrvatsko prijestolje dovede Zdeslava, Trpimirova sina koji se nalazio u egzilu u prijestolnici na Bosporu. Potonji je pokušaj bio kratkotrajan, jer je Zdeslav ubrzo pao kao žrtva atentata koji je na njega učinio Branimir, njegov takmac nepoznata porijekla. No ipak, i to pokazuje da je Bazilije nastojao iskoristiti slabljenje karolinškog utjecaja na Hrvate kako bi osnažio vlastiti. Branimir je još uvijek priznavao vrhovništvo Karla Debelog, iako je pokušavao izgraditi čvršće veze s papom Ivanom VIII., ali je nakon Karlove smrti 888. napokon nestao svaki oblik franačkog suvereniteta nad Hrvatima. Branimira je naslijedio Muncimir, Zdeslavov brat i, prema tome, vjerojatno sklon Bizantu (Budak 2008: 17).

Između posljednjeg spomena Muncimira 895. i splitskog crkvenog sabora 925., s iznimkom prvog spomena Tomislava 914., zarobljavanja duždeva sina od strane zahumskoga kneza Mihajla (912.) i vijesti o tome kako je Mihajlo otkrio Simeonu zavjeru koju su kovali drački protospatar Lav Rabduk i srpski knez Petar (917.), nemamo iz tog razdoblja izvore koji bismo sa sigurnošću datirali u tih tridesetak godina. ${ }^{7}$ Međutim, godine poslije 913 . razdoblje su intenzivnih napada Bugara na Bizant, što je za sobom povlačilo upade obiju strana u Srbiju, čiji su vladari mijenjali svoje saveznike u nastojanju da smanje nastalu štetu. U nekom su se času Hrvati uključili u ovaj sukob stajući na stranu Bizanta i podupirući Bizantu sklone srpske vladare. Vjerojatno 926. postigli su Hrvati znatnu pobjedu nad bugarskom vojskom koju je protiv njih poslao Simeon, a uz pomoć papinih izaslanika sklopljen je među zaraćenim stranama mir 927. ili godinu dana kasnije. Dojam što ga je ovaj hrvatski uspjeh ostavio na Bizant dokumentirao je Konstantin Porfirogenet, koji je zabilježio ne samo hrvatsku pobjedu nad bugarskim vojskovođom Alogoboturom, nego je iznio i znatno preuveličani podatak o veličini hrvatske vojske i mornarice (DAI, 150-151; 158-159). Ti podaci, ma kako nevjerojatni, bez sumnje su svjedočanstvo važnosti koju je Konstantin pridavao svojim hrvatskim saveznicima. ${ }^{8}$ Također se pobrinuo zapisati da Hrvati nisu nikad bili podložni Bugarima i da im nikad nisu plaćali danak, već da su s njima samo razmjenjivali darove (DAI, 150-151). Theophanes continuatus također je ostavio zapis o bugarskom porazu (Bekker 1838: 411).

Hrvatskom pomoći Bizantu u ovoj teškoj situaciji moglo bi se objasniti kako je Tomislav, prema HSM, proširio svoju upravu i na dalmatinske gradove. ${ }^{9} \mathrm{O}$ ovoj se temi puno raspravljalo, a mišljenja su se kretala od potpunog odbacivanja mogućnosti bilo kakve hrvatske kontrole nad gradovima prije sredine 11. st. do onih koja su tvrdila da je Tomislav proširio svoju vlast sve do sjeverno od Drača. ${ }^{10}$ Zaključivanje ovisi u velikoj mjeri o tome

6 O pitanju osnutka teme Dalmacije postoje brojni radovi. Prikaz diskusije može se naći u Margetić 2002: 503508. Nedavno je Tibor Živković uvjerljivo argumentirao tezu da je Dalmacija postala tema već između 817. i 821. (Živković 2001; 2008: 105-146). O Bazilijevoj odluci: DAl, 146-7.

7 Spomen Tomislava 914.: Toma Arhiđakon 2003 (dalje: HS), 53-55. Vijesti o Mihajlu: Monticolo 1890: 132; DAl, 157. Predrag Komatina ustvrdio je, kao što su prije njega to već učinili Daniele Farlati i Steven Runciman, da su Krešimir I. i Miroslav vladali prije Tomislava: Komatina 2010. lako je njegove argumente djelomično prihvatio Lončar 2010, ne mogu se složiti s ovakvim datiranjem. Bez ulaženja u detaljniju raspravu, htio bih upozoriti na to da je Komatina zaboravio da se Tomislav prvi put spominje 914., a ne 925., kako on tvrdi, a da je ban Pribina, koji je ubio Miroslava, prema ispravi iz 1066./67. držao banat u vrijeme Mihajla Krešimira II. (CD I, 106). Teško je zamisliti da bi bio u službi četrdesetak godina, koliko bi prema Komatininom datiranju proteklo od ubojstva Miroslava.

8 Tibor Živković je predložio drugačije i realističnije čitanje ovog pasusa, no ono zasad nije prihvaćeno. Za njegovo mišljenje i komentare na nj vidi: Živković 2007; Vedriš 2007.

9 Prema HSM, Tomislav je nazočio saboru u Splitu 925., što bi značilo da je vršio formalnu vlast nad Splitom i drugim dalmatinskim gradovima. Uvod u tekst koji govori o crkvenim saborima započinje datacijom: Tempore Joannis pape sanctissimo consulatu peragente in provintia Croatorum et Dalmatiarum finibus Tamislao rege et Michaele in suis finibus presidente duce. HSM, 98.

10 O Tomislavu, s uputama na daljnje čitanje: Raukar 1997: 35-40, 304-5; također: Budak 1994: 31-3. 
kako vrednujemo HSM. Vjerujemo li da su dodaci Tominu djelu autentični, onda moramo prihvatiti da se na crkvenim saborima 925. i 928. ne spominju nikakvi predstavnici bizantske vlasti. Jedini vladari su Tomislav s titulom rex Croatorum (na drugom saboru je sudjelovao kralj, ali ne znamo koji) i uz njega zahumski dux Mihajlo koji je možda sudjelovao samo na prvom saboru. Ne može se odbaciti pomisao da je Bizant Tomislava (a možda u tom času i Mihajla) smatrao predstavnikom svoje vlasti u Dalmaciji.

Može se činiti da jedina sačuvana suvremena dalmatinska isprava, oporuka zadarskog priora Andrije iz 918., proturiječi eventualnoj Tomislavovoj vlasti u Dalmaciji, jer se u njezinoj dataciji spominje samo car Konstantin. ${ }^{11}$ Međutim, ova oporuka prethodi splitskim saborima i hrvatsko-bugarskom sukobu. Osim toga, niti ona ne navodi bilo kakvog predstavnika bizantske vlasti u Dalmaciji, ukoliko to nije bio sam Andrija, ali to nikako ne bi slijedilo iz njegove titule priora. Još jedna isprava nastala je u Zadru krajem stoljeća (985./6.), napisana po nalogu zadarskog priora Maja, koji je ujedno bio i prokonzul Dalmacije, a datirana je suvladarstvom careva Bazilija II. i Konstantina VIII. (CD I, 44-6). Da je Andrija doista bio dalmatinski upravitelj, što bi se moglo očekivati od priora glavnoga grada, zasigurno bi to spomenuo u oporuci. Budući da to nije učinio, izostanak titule upravitelja Dalmacije ili podržava ono što piše u HSM o Tomislavu kao obnašatelju vlasti u Dalmaciji, ili govori u prilog nepostojanja stvarne bizantske ili bilo kakve centralne vlasti u priobalnim i otočkim gradovima, jer je spominjanje cara u dataciji moglo značiti i samo teoretsko prihvaćanje bizantskog vrhovništva. Zanimljivo je da se u oporuci Agape, kćeri tribuna Dabra, sastavljenoj 999., također spominju samo carevi Konstantin i Bazilije te prior Majo koji više nema titulu prokonzula (CD I, 48-49).

Može biti da se u Konstantinovo vrijeme situacija promijenila u odnosu na kraljevu ulogu u Dalmaciji. Car spominje rat koji je izbio među članovima hrvatske dinastije nakon ubojstva kralja Miroslava, vjerojatno oko 950. Posljedica rata bila je, prema Konstantinu, smanjena vojna snaga Hrvata (iako je nažalost propustio navesti brojeve pješaka, konjanika i brodova, mada je za to predvidio prazna mjesta u tekstu - ukoliko to nije bio propust prepisivača) (DAI, 150-151). Moguće je da je ovo slabljenje vojne moći, zajedno s prestankom bugarske opasnosti, omogućilo caru da počinje slati naredbe hrvatskom vladaru, kao što je to činio i s arhontima ostalih sklavinija na istočnom Jadranu (Reiske 1829: 691, 8-13). Jedan kasniji izvor, međutim - mada ne potpuno pouzdan - izgleda da potvrđuje da je i Mihajlo Krešimir II., Miroslavov nasljednik na prijestolju, imao neku vlast nad dalmatinskim gradovima, jer je zadarskom samostanu sv. Krševana, čini se, poklonio zemlju u Diklu koja se nalazila unutar gradskog agera. ${ }^{12}$ Bez autoriteta predstavnika carske vlasti to mu ne bi bilo moguće, osim ako zemlja nije bila njegovo privatno vlasništvo.

Konstantin navodi imena niza hrvatskih vladara, svojih suvremenika, ali izostavlja Tomislava. ${ }^{13}$ Često se pisalo o razlozima tog ispuštanja, ali je do toga možda došlo zbog toga što nije Tomislav, nego je njegov nasljednik Krešimir I. sklopio mir s Bugarima. Posljednji datirani spomen Tomislava je iz 925., pa je moguće da je do hrvatske pobjede nad Bugarima došlo nakon njegove smrti.

11 CD I, 25-28: In nomine domini nostri Jesu Christi et eiusdem incarnationis anno 908, indictione $7^{a}$, mense decembris. Imperante domino nostro Constantino piisimo ac perpetuo augusto. In ciuitate ladera. Godina 908. je prepisivačeva greška umjesto 918 .

12 U svojoj ispravi datiranoj u 1060-e, Petar Krešimir IV. spominje: Comperimus namque in gestis proaui nostri Cresimiri maioris, quod pro remedio anime sue tradidisse (!) monasterio sancti Chrisogoni aliquod loco, qui dicitur Hyculus.... CD I, 105-6. Ova je zemlja, do danas poznata kao Diklo, bila dio zadarskog agera. Vidi Jakšić 1987-1988.

13 DAI, 150-1. Konstantin također umeće u ovu listu, najvjerojatnije krivo, inače nepoznatog Trpimira II., kojeg bi se možda moglo identificirati kao Trpimira iz sredine 9. st. DAI, 148-149. Vidi bilj. 7. 
Je li u prvim desetljećima 10. st. došlo do naglog porasta vojne moći Hrvata, i ako jest, koji su tome bili uzroci? Ili postoji neko drugo objašnjenje za iznenadno pojavljivanje Hrvata u izvorima različite provenijencije? Konstantin je naveo da su se Hrvati borili protiv Bugara već u vrijeme Mihajla Borisa (DAI, 150-1). Rat je završio bez pobjednika, što znači da su Hrvati već tada raspolagali vojnom snagom dostatnom za pružanje otpora jakom protivniku. $\mathrm{Ne}$ smijemo zaboraviti da ni Mlečani nisu bili u stanju spriječiti napade slavenskih pirata tijekom 9. i 10. st. (Lane 1973: 24-26; Budak 1994: 22-28; Raukar 1997: 40-42). Dakle, vjerojatno nije došlo do nekog naglog porasta vojne moći Hrvata prije Konstantinova vremena, nego se hrvatsko ime počelo pojavljivati u tekstovima nastalima izvan Hrvatske zbog rastućeg zanimanja za događanja u regiji. Gotovo ništa od onoga što se zbivalo na istočnom Jadranu u drugoj polovici 9. st. nije bilo predmetom interesa „međunarodne zajednice“. Samo su pape održavali bliže veze s hrvatskim vladarima, jer su ovi trebali osiguravati veze Rima s Bugarima dok se vodila borba između Rima i Carigrada za crkvenu prevlast nad novopokrštenim narodom (Schimmelpfennig 1988: 110-111; Ostrogorski 2006: 134). ${ }^{14}$ Osim toga, nejasno je u kojoj je mjeri hrvatsko ime bilo etablirano u samoj Hrvatskoj. Trpimirova je dinastija imala velikih poteškoća u nastojanjima da se ustali na prijestolju i dva je puta bila zbačena od pripadnika drugih klanova (Budak 1997: 17). To znači da suprotstavljenim klanovima nije bilo nimalo jednostavno stabilizirati vlast. Čini se da je do smirivanja došlo tek s usponom Muncimira na prijestolje. ${ }^{15}$ Ova konsolidacija vlasti, koja je izgleda potrajala do oko 950., omogućila je hrvatskim vladarima podizanje veće vojske s kojom su se mogli suprotstaviti Bugarima efikasnije nego prije, a možda su mogli steći i nadzor nad dijelom Panonije. Konstantin spominje i kako su izbjeglice iz Moravske, nakon propasti njihove kneževine, našli pribježište u susjednoj Hrvatskoj, kao i Srbi koji su bježali pred Simeonom. Konstantin je također jedini autor koji tvrdi da su Hrvati (iako on misli da je to bilo po doseljenju) zavladali Panonijom i llirikom (DAI, 142-3; o Hrvatima u Panoniji Gračanin 2008). Arheologija potvrđuje bliske veze Hrvatske s jugozapadnim dijelom panonske nizine u široj okolici Siska (Mikecz 2009; Sokol 1997; 2006).

Još jedan mogući znak rastuće snage Hrvata i njihovog sve većeg utjecaja u regiji bila je hijerarhija titula korištenih na području antičke Dalmacije. U HSM Tomislav je nekoliko puta naveden kao rex, dok Mihajlo, vladar Zahumljana, nosi titulu dux. Može li to značiti da je Mihajlo na neki način priznavao podređenost hrvatskom kralju? ${ }^{16}$ Odgovor na to možda daje podatak iz kronike Ivana Đakona koji je, opisujući događaje 912., napisao da je duždevog sina Petra, dok je prolazio hrvatskim zemljama, zarobio knez Mihajlo. ${ }^{17}$ Ako je Mihajlo djelovao unutar hrvatskih granica, može se pomišljati da je bio podanik hrvatskoga kralja. Međutim, nakon nekog vremena (možda poslije unutarnjih sukoba u Hrvatskoj)

14 O odnosima Hrvata i Rima u drugoj polovici 9. st. Ančić 2002: 52-55; Jakšić 2002: 241-245.; 2006. Kritički osvrt na Ančića i Jakšića: Matijević Sokol 2007.

15 lako nema nikakvih dokaza rodbinskih odnosa Muncimira i Tomislava, uobičajna je pretpostavka hrvatske historiografije da se radi o pripadnicima iste dinastije Trpimirovića. Imena vladara iz 10. st. nisu ista kao ona Trpimirovića u 9. st., s izuzetkom Trpimira Il., za kojeg možemo sumnjati je li uopće postojao. Prihvatimo li Komatinine argumente o identičnosti Trpimira II. s osnivačem dinastije Trpimirovića, onda otpada i ovaj slabašni argument da je riječ o kontinuitetu vladarske loze. Za vijest o Trpimiru II.: DAI, 148-151.

16 Mladen Ančić u nekoliko se navrata pozabavio pitanjem Humskog kneštva i Zahumlja, odnosno Neretvanske kneževine, pa tako i položajem Mihajla Viševića. Uočivši niz problematičnih tumačenja starijih povjesničara koji su se bavili vrelima u kojima se spominju etnije Neretvana i Zahumljana, odnosno odgovarajuće sklavinije, doveo je u pitanje postojanje Neretvana kao zasebnog etnosa i Neretvanske kneževine kao samosvojne političke tvorbe. Usprkos nizu zanimljivih opažanja i argumentiranih prijedloga, nisam uvjeren da je uspio u potpunosti dokazati svoje mišljenje, ali bi rasprava o tome iziskivala posebni tekst. Vidi Ančić 2011a; 2011 b.

17 Rački 1877 (dalje: Documenta), 388: Qui dum Chroatorum fines rediens transire vellet, a Michaele Sclavorum duce fraude deceptus, omnibusque bonis privatus, atque Vulgarico regi, Simeoni nomine, exilii pena transmissus est. 
promijenio je svoj položaj i prihvatio vrhovništvo srpskog vladara, jer Konstantin tvrdi da su Zahumljani bili Srbi od vremena onog arhonta koji je Srbe, za vrijeme Heraklija, doveo u njihovu novu domovinu (DAI, 160-1). Ta tvrdnja, naravno, nema veze sa stvarnošću 7. st., ali govori o političkim odnosima u Konstantinovo vrijeme (Budak 1990). Kao bizantski saveznik, usprkos tome što je u vrijeme Simeona podupirao Bugare, Mihajlo je dobio visoke titule prokonzula (antipata) i patricija. ${ }^{18}$ Događaj iz 912. bi mogao upućivati na to da Hrvati tada još nisu stajali čvrsto uz Bizant, već su još uvijek pokušavali održavati, kako se čini, dobre odnose s Bugarima. Možda je upravo poklon u obliku uprave nad dalmatinskim gradovima naveo Hrvate da promijene politiku. Mihajlo je u srpnju 926. napao i opljačkao Sipont. Iz šture vijesti Barijskih anala ne može se razaznati razlog tog pothvata, pa je moguće da je zahumski vladar osvojio grad za račun Bizanta, budući da su ga pet godina prije možda osvojili langobardski pobunjenici protiv carske vlasti (Churchill 1979: 201-202). ${ }^{19}$ Titula rex, koju mu pripisuju „Barski anali“, upućuje na njegov samostalni položaj. Uostalom, odnos se dvojice vladara mogao promijeniti od 925. do 926. godine, tako da se Mihajlo doista osamostalio. Moramo ipak imati u vidu da je svaki pokušaj rekonstrukcije događaja u prvoj polovici 10. st. suočen s ozbiljnim nedostatkom izvora i s nesigurnim datiranjima.

Druga polovica 10. st. nije nam ostavila puno više izvora od prve. Ipak, Toma Arhiđakon nas obavještava o važnom događaju:

Ab isti Dirsisclavo ceteri successores eius reges Dalmatie et Chroatie appellati sunt. Recipiebant enim regie dignitatis insignia ab imperatoribus Constantinopolitanis et dicebantur eorum eparchi sive patricii (HS, 54-55).

Tominu vijest treba razumjeti tako da su hrvatski vladari, koji su se i dotad koristili titulom rex (Croatorum), otad tu gentilnu titulu zamijenili teritorijalnom, označavajući se kraljevima Hrvatske i Dalmacije, a ne više kraljevima Hrvata.

Ako povučemo analogiju sa situacijom u 9. st., kada je Borna nosio gentilnu titulu dux Guduscanorum i teritorijalnu titulu dux Dalmatiae atquae Liburniae, možemo nazrijeti promjene u odnosima hrvatskih vladara i bizantskih careva (Budak 1997: 15-16). Naime, razlika u Borninoj titulaturi proizlazila je iz toga što je on bio vladar Gudučana, ali je u franačkoj službi postao upraviteljem Dalmacije i Liburnije. Po analogiji bismo trebali zaključiti da je i teritorijalna titula hrvatskih vladara proizlazila iz toga što im je bila dana od bizantskih careva: oni su sami po sebi bili kraljevi Hrvata, ali su voljom cara postali upravitelji Hrvatske i Dalmacije, bez obzira na to kakav je bio stvarni utjecaj Bizanta na tom području. Zapitamo li se kada je moglo doći do te promjene, mogući nam odgovor nudi spomenuti Tomin ulomak u kombinaciji s epitafom kraljice Jelene (Delonga 1996: 131-134).

Na kraljičinom je epitafu iz 976. zabilježeno da je bila žena kralja Mihajla i majka kralja Stjepana. Ako je te godine Držislav već nosio ime Stjepan, mogli bismo pretpostaviti da je tada već primio kraljevske oznake iz Carigrada. Ime Stjepan upućuje na čin ovjenčanja, odnosno krunidbe. Najbliži su primjeri onaj Stjepana I. Arpadovića ili Stefana Nemanje.

Bizant je prije 976. imao razloga osigurati podršku Hrvata na zapadu. Godine 968. ruski vladar Svjatoslav privremeno je osvojio Bugarsku i ugrozio Bizant, sljedeće je godine ubijen Nicifor Foka, carstvo je bilo zaokupljeno ratovima na istoku i nalazilo se pod pritiskom Otona I. u Italiji (Ostrogorski 2006: 169-172; Stephenson 2000: 47-80). ${ }^{20}$

18 O njegovim titulama: DAl, 160-1. Epizoda koja pokazuje da je barem privremeno podržavao Simeona: DAl, 156-7.

19 Churchill 1979: 116: Hoc anno comprehendit Michael rex Sclauorum ciuitatem Sipontum, mense Iulio, die sancte Felicitatis, secunda feria, indictione quintadecima.

20 Za različita mišljenja o tome kada je Dalmacija predana hrvatskom kralju Ferluga 1957: 87-88. Nedavno je o odnosima Hrvata i Bizanta u drugoj polovici 10. st. pisao Ančić 2010; također Raukar 1997: 39-40. 
U takvim se okolnostima moglo činiti mudrim osigurati istočnu jadransku obalu, a dodjeljivanje titule eparha i patricija uza slanje adekvatnih insignija bio je dosta jeftin način da se to postigne, pogotovo što su ionako dalmatinski gradovi hrvatskom vladaru već plaćali tribut još od Bazilija I. Hrvatskom se kralju moglo činiti da se znatno uspeo na hijerarhiji vlasti, dobivši potvrdu svojeg visokog položaja, dok je s druge strane zapravo prihvatio položaj bizantskog eparha, odnosno upravitelja pokrajine. Kasniji postupak Bazilija II. prema Krešimiru III. i Gojslavu pokazat će da su carevi na Bosporu upravo tako shvaćali njihov međusobni odnos, odnosno da su i dalje na „upravitelje“ Hrvatske i Dalmacije gledali kao na arhonte kojima mogu slati naredbe. ${ }^{21}$ Iz već spomenutog dokumenta iz 985./6. mogli bismo zaključiti da Dalmatinci nisu obraćali previše pažnje na hrvatskog vladara, jer se u dataciji spominju samo carevi Bazilije i Konstantin, dok prior Majo nosi titulu prokonzula, odnosno upravitelja Dalmacije. Hrvatski se kralj ne spominje u dataciji, iako se navodi kasnije u tekstu isprave. ${ }^{22}$ Ovo bi se moglo tumačiti i tako da je kralj kao eparh Hrvatske i Dalmacije bio podređen caru, ali nadređen prokonzulu Dalmacije, koji, međutim, nije držao nužnim navesti ga u dataciji isprave.

Stjepan Držislav ostavio je tri sina koji su uskoro započeli sukob oko prijestolja (Klaić 1975: 320-334). Time je ponovno oslabljena vojna moć kraljevstva, pa je dužd Petar II. Orseolo iskoristio priliku kako bi pokrenuo pohod protiv slavenskih vladara na istočnom Jadranu. Rezultat te vojne akcije bio je taj da je dužd zamijenio hrvatske kraljeve kao upravitelj Dalmacije, uzimajući titulu dux Dalmatie (Lane 1973: 26). Godine 1018. dva brata - Krešimir III. i Gojslav - koji su kao suvladari vladali Hrvatskom, otišli su pred Bazilija II. i potvrdili da prihvaćaju vrhovništvo pobjedonosnog cara. U zamjenu su dobili titule patricija. ${ }^{23}$ Skilica, koji izvještava o ovom susretu, ne spominje titulu eparha, što ne treba čuditi s obzirom na to da je Petar II. Orseolo svoj pothvat izveo uz carevo dopuštenje. Godine 1024. katepan Bazilije Bojoan preplovio je Jadran i zarobio ženu kralja (vjerojatno Krešimira III.), koja je navedena kao patricissa. Poslao ju je, zajedno s njezinim sinom, u Carigrad i o njoj više nemamo nikakve vijesti (Klaić 1975: 330). ${ }^{24}$

${ }_{21}$ Već je Jadran Ferluga 1978: 192-194, pretpostavio da se titula eparha odnosila na staru rimsku provinciju Dalmaciju. Lujo Margetić nije se s time složio, tvrdeći da je titula eparha dana Držislavu zbog bugarske opasnosti i da je značila samo pravo ubiranja prihoda od dalmatinskih gradova i utjecanja na njihovu politiku, ali da mu nije davala ovlasti vojnog zapovjedništva nad lokalnom milicijom. Margetić je također tvrdio da titula patricija nije bila samo simbolična, nego je predviđala redoviti prihod. Margetić 1994.

$22 \mathrm{CD}$ I, 45: Hec omnia non speciali nostro consilio, sed omnibus consentientibus ciuibus ad saluationem predicte ciuitatis et populi ordinauimus et constituimus atque firmamus, ut, si aliquo diabolico spiritu impletus, quod non optamus, contra uos uestrosque successores molestiam de rebus aut substantiis fecerit de supradicta ecclesia, habeatis licentiam cum hac cartula traditionis in iudicium uenire atque monstrare ante imperatorem, ante regem, ante comitem siue iudices, qui pro tempore fuerint, ut nichil aliquid de supradicta causa subtrahere possunt. Spominjanje kneza moglo bi značiti da su svi dostojanstvenici navedeni poslije cara spomenuti samo kao teoretska mogućnost, jer u to vrijeme nitko ni u Hrvatskoj, niti u Dalmaciji nije nosio titulu komesa. Moguće ja, naravno, da je pisar pod tom titulom podrazumijevao nekog drugog. Držislavov natpis iz Knina, naime, spominje vladara kao dux magnus, dok uz njega postoji još jedan dux, što znači da je uz vladara postojao još barem jedan visoki dostojanstvenik osim bana, a titule dux i comes bile su, barem u 9. st., smatrane sinonimima. Dakako, titula komesa možda svjedoči o kasnijoj preradi isprave, kada su gradovima upravljali komesi, ali se onda postavlja pitanje zašto bi se u tom slučaju spominjao car? Za kninski natpis: Delonga 1996: 108.

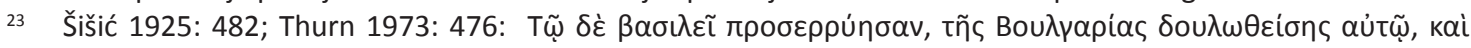

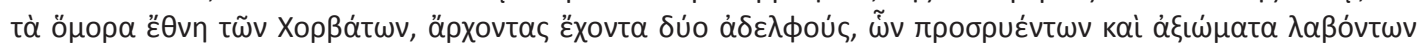

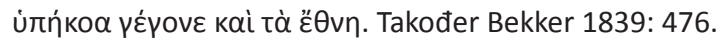

24 Documenta, 434, donose fragment iz Lupi protospatharii chronicon: Anno 1024 ... In hoc anno cecidit nix magna. Et in hoc anno transferavit Bugiano in Chorvatia, et comprehendit ipsam patrocissam uxorem Cismigi, et direxit illam Constantinopolim. I Chronicon Barense donosi sličnu vijest: Millesimo XXIV, indictione VII. Barchavit Bugiano in Corbatia cum Barenses, et compraehendit ipsam patricissa uxor Cosmizi, et adduxit illam in Bari, misitque eam cum filio suo in Constantinopoli. 
Čini mi se da ovaj kratki pregled hrvatsko-bizantskih odnosa pokazuje da je pitanje bizantske nazočnosti na istočnom Jadranu još uvijek otvoreno za raspravu. Nakon što je Nikola Jakšić interpretirao nekoliko grobnih nalaza kao dokaze bizantske vojne prisutnosti u središnjoj Dalmaciji u 8. st., a Tibor Živković uvjerljivo argumentirao tezu o osnivanju teme Dalmacije odmah po sklapanju Aachenskog mira, postalo je jasno da Bizant nije bio samo nominalni suveren područja koje je bilo od životne važnosti za održavanje pomorske veze $s$ Venecijom. Bizantsku politiku treba promatrati i u svjetlu intenziviranja trgovačkih i putničkih veza i rastuće važnosti Venecije od sredine 8. st., kao i s prisutnošću bizantske flote na Jadranu (McCormick 2001: 523-531). Vojni pothvat nekog bizantskog patricija u vrijeme Trpimira (Budak 1994: 73), kao i Zdeslavov dolazak na prijestolje uz pomoć Bazilija I., također potvrđuju bizantsku vojnu nazočnost duž istočnojadranske obale. Bazilije I. naredio je Dalmatincima da danak koji su dotad plaćali svojem strategu preusmjere u riznicu hrvatskog vladara i arhonata Zahumlja i Travunije. Je li to bilo samo kupovanje mira, ili je to - s obzirom da je iznos namijenjen hrvatskom vladaru bio onaj koji je dobivao strateg - bio znak da je knez Hrvata preuzeo i neka upravljačka prava nad dalmatinskim gradovima? lako na ovo pitanje ne možemo dati konačni odgovor, dobro je prisjetiti se da nakon ubojstva Zdeslava ipak nema nikakvih vijesti o neprijateljstvima između Hrvata i Dalmatinaca. Dapače, vijesti vezane uz crkvene odnose govore upravo suprotno, budući da je u vrijeme Branimira napravljen prvi korak objedinjavanju Ninske biskupije i Salonitansko-splitske nadbiskupije (Budak 2003: 87-88). Branimira je naslijedio Muncimir, Trpimirov sin, za kojega s razlogom možemo vjerovati da je održavao dobre odnose $s$ Bizantom i koji se vjerojatno upleo u unutrašnje prilike u Srbiji, nudeći azil izbjeglim članovima srpske vladarske dinastije (DAI, 154-157; Ćirković 2004: 17-18). Tomislav je nastavio pomagati Srbe koji su se suprotstavili Bugarima, a Hrvati su se i sami sukobili sa Simeonom. Veze hrvatskog dvora s Carigradom dodatno su ojačale u vrijeme Stjepana I. Držislava. Naši nam izvori, dakle, dopuštaju pomisao da su Hrvatski vladari sve do kraja 10. st. na neki način upravljali dalmatinskim gradovima kao predstavnici bizantske vlasti. To ne znači da je Bizant poslije Bazilija I. držao vlastite vojne snage u Dalmaciji, ali je njegov autoritet bio dovoljno jak da hrvatske vladare navede da djeluju kao dio bizantske administrativne hijerarhije. Kroz svo to vrijeme ni Venecija nije poduzimala vojne akcije protiv hrvatskih uporišta ili brodova.

Situacija se promijenila nakon smrti Stjepana I., kada je među njegovim sinovima izbio sukob (Šišić 1925: 472-473). Kako je Bazilije II. bio u potpunosti zaokupljen ratovanjem s Bugarima, dinastički sukob u Hrvatskoj ponukao je Petra Orseola da poduzme ekspediciju kojoj je cilj bio zamijeniti hrvatske vladare na mjestu upravitelja Dalmacije. Učinio je to uz pristanak Carigrada, što je Krešimira III. i Gojslava natjeralo da se okrenu protiv Bizanta u pokušaju da vrate nadzor nad dalmatinskim gradovima. ${ }^{25}$ Nakon što se obračunao sa Samuilom, Bazilije II. je 1019. natjerao braću da ponovo priznaju njegovu vlast, ali je Krešimir, nakon što je poslije bratove smrti, kako se čini, ostao sam na prijestolju, nastavio s pokušajima da Veneciji preotme gradove, izazvavši time Bazilija da protiv njega iz Italije uputi Bazilija Bojoana. Bio je to početak sukoba koji će u vrijeme Petra Krešimira IV. rezultirati hrvatskim pripajanjem Dalmacije.

25 Svetoslav je ostao duždev saveznik, a shodno tome i Bazilijev. On je u Trogiru dočekao Orseola i predao mu svojeg sina koji se kasnije oženio duždevom kćerkom. Monticolo 1890: 155. 


\section{POPIS LITERATURE}

\section{ANČIĆ 1997}

Mladen Ančić, „From Carolingian Official to Croatian Ruler - The Croats and the Carolingian Empire in the First Half of the Ninth Century", Hortus artium medievalium, 3, Zagreb 1997., 7-13.

\section{ANČIĆ 1998}

Mladen Ančić, „The Wanning of the Empire. The Disintegration of Byzantine Rule on the Eastern Adriatic in the $9^{\text {th }}$ Century", Hortus artium medievalium, 4, Zagreb 1998., 15-24.

\section{ANČIĆ 2002}

Mladen Ančić, „Mjesto Branimirove Hrvatske u suvremenom svjetskom poretku“, u: Šime Batović (ur.), Hrvatska u doba kneza Branimira, Zadar 2002., 43-65.

\section{ANČIĆ 2010}

Mladen Ančić, „Zamišljanje tradicije: vrijeme i okolnosti postanka 30. glave djela De administrando imperio", Radovi Zavoda za hrvatsku povijest, 42, Zagreb 2010., 133-151.

\section{ANČIĆ 2011A}

Mladen Ančić, „Ranosrednjovjekovni Neretvani ili Humljani: Tragom zabune koju je prouzročilo djelo De administrando imperio“, u: Ivica Lučić (ur.), Hum i Hercegovina kroz povijest, Zbornik radova, knj. 1, Zagreb 2011., 218-278.

\section{ANČIĆ 2011B}

Mladen Ančić, „Miho Barada i mit o Neretvanima“, Povijesni prilozi, 41, Zagreb 2011., 17-43.

\section{BEKKER 1838}

Immanuel Bekker (ur.), Theophanes continuatus, loannes Cameniata, Symeon Magister, Georgius Monachus, Bonn 1838.

\section{BEKKER 1839}

Immanuel Bekker (ur.), Georgius Cedrenus. Compendium historiarum, vol. 2., Bonn 1839.

\section{BUDAK 1990}

Neven Budak, „Die Südslawischen Ethnogenesen an der östlichen Adriaküste im Frühen Mittelalter", u: Herwig Wolfram i Walter Pohl (ur.), Typen der Ethnogenesen unter besonderer Berücksichtigung der Bayern, vol. I, Beč 1990., 129-136.

\section{BUDAK 1994}

Neven Budak, Prva stoljeća Hrvatske, Zagreb 1994.

\section{BUDAK 1997}

Neven Budak, „Croats Between Franks and Byzantium", Hortus artium medievalium, 3, Zagreb 1997., 15-22.

\section{BUDAK 2003}

Neven Budak, „Polaganje temelja Kraljevstva Hrvatske i Dalmacije", u: Franjo Šanjek (ur.), Povijest Hrvata. Srednji vijek, Zagreb 2003., 84113.

\section{BUDAK 2008}

Neven Budak, „Identities in Early Medieval Dalmatia", u: Ildar Garipzanov, Patrick Geary i Przemysław Urbańczyk (ur.), Franks, Northmen, and Slavs. Identities and State Formation in Early Medieval Europe, Turnhout 2008., 223-41.

\section{BUDAK 2009}

Neven Budak, „Kako se doista s jugonostalgičarskih pozicija može negirati hrvatska povijest ili o knjizi Johna V. A. Finea Ml. When Ethnicity did not Matter in the Balkans. A Study of Identity in Pre-Nationalist Croatia, Dalmatia, and Slavonia in the Medieval and Early-Modern Periods, Ann Arbor: The University of Michigan Press 2006", Radovi Zavoda za hrvatsku povijest, 41, Zagreb 2009., 487-95.

\section{BUDAK 2013}

Neven Budak, „Historia Salonitana and Historia Salonitana Maior: a contribution to the debate about the relation of the two texts", u: Mirna Willer - Marijana Tomić (ur.), Summer School in the Study of Historical Manuscripts, Zadar 2013., 101-131.

\section{CHURCHILL 1979}

The Annales barenses and the Annales Lupi Protospatharii: Critical Edition and Commentary, A Dissertation submitted 
in conformity with the requirements for the Degree of Doctor of Philosphy in the University of Toronto 1979 (http://www. billchurchill.com/Dissertation/ChurchillDissertation.html-posjet ostvaren 18. 6. 2014.).

\section{ĆIRKOVIĆ 2004}

Sima Ćirković, The Serbs, Oxford 2004.

\section{DELONGA 1996}

Vedrana Delonga, Latinski epigrafički spomenici u ranosrednjovjekovnoj Hrvatskoj, Split 1996.

\section{DZINO 2009}

Danijel Dzino, „Novi pristupi izučavanju ranog hrvatskog identiteta", Radovi Zavoda za hrvatsku povijest, 41, Zagreb 2009., 33-54.

\section{DZINO 2010}

Danijel Dzino, Becoming Slav, Becoming Croat. Identity Transformations in Post-Roman and Early Medieval Dalmatia, Turnhout 2010.

\section{FERLUGA 1957}

Jadran Ferluga, Vizantiska uprava u Dalmaciji, Beograd 1957.

\section{FERLUGA 1978}

Ferluga, L'amministrazione bizantina in Dalmazia, Venecija 1978.

\section{FINE 2006}

John V. A. Fine, Jr., When Ethnicity did not matter in the Balkans. A Study of Identity in Pre-Nationalist Croatia, Dalmatia, and Slavonia in the Medieval and Early-Modern Periods, Ann Arbor 2006.

\section{GOLDSTEIN 1992}

Ivo Goldstein, Bizant na Jadranu, Zagreb 1992.

\section{GOLDSTEIN 1998}

Ivo Goldstein, "Byzantium on the Adriatic", Hortus artium medievalium, 4, Zagreb 1998., 7-14.

\section{GRAČANIN 2008}

Hrvoje Gračanin. „”Od Hrvata pak koji su stigli u Dalmaciju odvojio se jedan dio i zavladao llirikom i Panonijom". Razmatranja uz DAI c. 30", Povijest u nastavi, 6, Zagreb 2008., 1 (11), 6776.

\section{JAKŠIĆ 1987-1988}

Nikola Jakšić, „Draga sv. Krševana u Diklu o tisućitoj obljetnici osnutka samostana", Radovi Filozofskog fakulteta u Zadru, 27, Zadar 1987-8., 115-133.

\section{JAKŠIĆ 2002}

Nikola Jakšić, "On the Origin of the Baptismal Font with the Name of Prince Višeslav", Hortus Artium Medievalium, 8, Zagreb 2002., 241-245.

\section{JAKŠIĆ 2006}

Nikola Jakšić, „Manipulacija povijesnim spomenicima - primjer Višeslavove krstionice“, u: Marijana Marinović (ur.), Povijesno naslijeđe $i$ nacionalni identitet, Zagreb 2006., 40-45.

\section{JAKŠIĆ 2008}

Nikola Jakšić, „Il ruolo delle antiche chiese rurali nella formazione del ducato croato medievale", Hortus artium medievalium, 14, Zagreb 2008., 103-112.

\section{KLAIĆ 1967}

Nada Klaić, Historia salonitana maior, Beograd 1967.

\section{KLAIĆ 1975}

Nada Klaić, Povijest Hrvata u ranom srednjem vijeku, Zagreb 1975.

\section{KOMATINA 2010}

Predrag Komatina, „O hronologiji hrvatskih vladara u 31. glavi spisa De administrando imperio", Radovi Zavoda za hrvatsku povijest, 42, Zagreb 2010., 83-105.

\section{KRONSTEINER 1978}

Otto Kronsteiner, "Gab es unter den Alpenslawen eine kroatische ethnische Gruppe?", Österreichische Namensforschung, 6, Beč 1978., 79-99.

\section{LANE 1973}

Frederic C. Lane, Venice. A Maritime Republic, Baltimore i London 1973.

\section{LONČAR 2010}

Milenko Lončar, „Vremenski nesklad između odlomaka 31. poglavlja De administrando imperio", Radovi Zavoda za hrvatsku povijest, 42, Zagreb 2010., 107-116. 


\section{MARGETIĆ 1993}

Lujo Margetić, „Bilješke uz Trpimirovu ispravu (CD I, 3-8)", Zbornik radova Pravnog fakulteta u Splitu, 30/1, Split 1993.

\section{MARGETIĆ 1994}

Lujo Margetić, „Kralj Stjepan Držislav, bizantski eparh i patricij", u: Margetić, Prikazi i diskusije, Split: Književni krug 2002, 386-391; izvorno objavljeno u Historijski zbornik, 47, Zagreb 1994., 13-18.

\section{MARGETIĆ 2002}

Lujo Margetić, Prikazi i diskusije, Split: Književni krug 2002.

\section{MATIJEVIĆ SOKOL 2007}

Mirjana Matijević Sokol, „Krsni zdenac Hrvata. Paleografsko-epigrafska raščlamba natpisa...", Croatica Christiana Periodica, 59, Zagreb 2007., 1-31.

\section{MATIJEVIĆ SOKOL 2010}

Mirjana Matijević Sokol, „1150. obljetnica darovnice kneza Trpimira", Izdanja HAD-a 25, Zagreb 2010.

\section{MCCORMICK 2001}

Michael McCormick, Origins of the European Economy. Communications and Commerce $A D$ 300-900, Cambridge 2001.

\section{MIKECZ 2009}

Jeremy Mikecz, The Place that Lies Between: Slavonia in the $10^{\text {th }}$ and $11^{\text {th }}$ Centuries, MA Thesis, Central European University, Budapest 2009.

\section{MONTICOLO 1890}

Giovanni Monticolo, Cronache veneziane antichissime, Fontes storie italiane 9, Rim 1890.

\section{MORAVCSIK - JENKINS 1967}

Gyula Moravcsik i R. J. H. Jenkins (ur.), Constantine Porphyrogenitus, De administrando imperio, Dumbarton Oaks 1967.

\section{OSTROGORSKI 2006}

Georgije Ostrogorski, Povijest Bizanta 324 1453, Zagreb 2006.

\section{POHL 1988}

Walter Pohl, Die Awaren: Ein Steppenvolk im Mitteleuropa, München 1988.

\section{PROZOROV 2006}

Vadim Prozorov, "The Passion of St. Domnius: The Tradition of Apostolic Succession in Dalmatia", u: Scrinium, vol. 2: Universum Hagiographicum. Mémorial R. P. Michel van Esbroeck, S.J. (1934-2003), B. Lourié i A. Mouraviev (ur.), Petrograd - Moskva 2006., 219-239.

\section{PROZOROV 2012}

Vadim Prozorov, "Where he is, thither will the eagles be gathered together: The metropolitan status of the bishop of Spalato from the decline of Salona until the councils of Spalato in 925 and 928", u: John S. Ott - Trpimir Vedriš (ur.), Saintly bishops and bishops' saints, Bibliotheca Hagiotheca, Series Colloquia, sv. 2., Zagreb 2012., 103-122.

\section{RAČKI 1877}

Franjo Rački, Documenta historiae chroaticae periodum antiquam illustrantia, Zagreb 1877.

\section{RAUKAR 1997}

Tomislav Raukar, Hrvatsko srednjovjekovlje, Zagreb 1997.

\section{REISKE 1829}

Jochan Jacob Reiske (ur.), Constantini Porphyrogeniti imperatoris de cerimoniis aulae Byzantinae libri duo, vol. 1. Corpus scriptorum historiae Byzantinae, Bonn 1829.

\section{SOKOL 1997}

Vladimir Sokol, „Arheološka baština i zlatarstvo", u: Hrvatska i Europa. Kultura, znanosti i umjetnost, vol. I, Ivan Supičić (ur.), Zagreb 1997., 117-146.

\section{SOKOL 2006}

Vladimir Sokol, Hrvatska srednjovjekovna arheološka baština od Jadrana do Save, Zagreb 2006.

\section{STEPHENSON 2000}

Paul Stephenson, Byzantium's Balkan Frontier. A Political Study of the Northern Balkans, 9001204, Cambridge 2000. 


\section{STIPIŠIĆ - ŠAMŠALOVIĆ 1967}

Codex diplomaticus regni Croatiae, Dalmatiae et Slavoniae, Jakov Stipišić i Miljen Šamšalović (ur.), Zagreb 1967.

\section{Šı̌̌ıć 1925}

Ferdo Šišić, Povijest Hrvata u vrijeme narodnih vladara, Zagreb 1925.

\section{TOMA ARHIĐAKON 2003}

Toma Arhiđakon, Historia Salonitana, Split 2003.

\section{THURN 1973}

Hans (Johannes) Thurn (ur.), loannis Scylitzae Synopsis Historiarum. Corpus fontium historiae Byzantinae, Series Berolinensis 5. Berlin - New York 1973.

\section{VEDRIŠ 2007}

Trpimir Vedriš, „Povodom novog tumačenja vijesti Konstantina VII. Porfirogeneta o snazi hrvatske vojske", Historijski Zbornik, 60, Zagreb 2007., 1-33.

\section{ZLATARSKI 1927}

Vasil Zlatarski, Istoria na b'lgarskata država prez srednite vekove, Sofia 1927.

\section{ŽıVKOVIĆ 2001}

Tibor Živković, „Taktikon Uspenskog i tema Dalmacija", Istorijski časopis, 48, Beograd 2001., 9-44.

\section{ŽIVKOVIĆ 2008}

Tibor Živković, Forging Unity: The South Slavs Between East and West: 550-1150, Beograd 2008.

\section{ŽıVKOVIĆ 2007}

Tibor Živković, „Contribution to the New Reading about the Constantine Porphyrogenitus' Statement on the Numbers of Croat Horsmen, Foot Soldiers and Sailors in Early 10th Century", Byzantinoslavica, 65, Prag 2007., 1-9.

\section{SAŽETAK}

Tijekom 9. st. hrvatsko je ime bilo poznato samo unutar granica Hrvatske. Razni autori koji su pisali o području antičke Dalmacije stanovništvo su nazivali Slavenima ili Dalmatincima. Od prve četvrtine 10. st., međutim, to se mijenja i hrvatsko ime se pojavljuje u izvorima pisanim u Veneciji, Rimu i Carigradu, od kojih je najvažniji "De administrando imperio“ Konstantina VII. Porfirogeneta. Rast zanimanja za Hrvatsku i Hrvate može se protumačiti događajima vezanim uz hrvatsko-bugarski sukob, koji je bio posljedica bizantskog ratovanja protiv Simeona. Čini se da je Bizant, u želji da privuče Hrvate na svoju stranu, hrvatskim vladarima prepustio upravu nad dalmatinskim gradovima koji su priznavali nominalnu bizantsku vlast. Onovremena važnost Hrvata bila je posljedica njihove vojne snage koja se očitovala i u pretjerano velikim brojevima hrvatskih ratnika koje navodi Konstantin. Nakon duljeg vremena nestabilnosti u drugoj polovici 9. st., čini se da se krajem stoljeća Trpimirova dinastija uspjela ustaliti na prijestolju. To je Hrvatima omogućilo da preuzmu aktivniju ulogu na Balkanu. Nova dimenzija u odnosima Hrvata i Bizanta dosegnuta je, čini se, poslije 968., kada je Svjatoslav osvojio Bugarsku i ugrozio carstvo, dok je istovremeno Bizant bio suočen s teškoćama u južnoj Italiji. Ivan I. Cimisk odlučio je osigurati lojalnost Hrvata time što je njihovom vladaru poslao krunu i učinio ga kraljem Hrvatske i Dalmacije. Istovremeno ga je, međutim, proglasio eparhom, pokazujući time njegov ovisan položaj. Odnos kralja i cara jasno pokazuje način na koji je Bazilije II. natjerao Krešimira III. i Gojslava da priznaju njegovo vrhovništvo. 


\section{SUMMARY}

\section{Croatia and Byzantium in $10^{\text {th }}$ Century}

During the ninth century the name of Croats was known only within their realm. Different authors reporting about ancient Dalmatia described the population as Slavs or Dalmatians. However, since the first quarter of the tenth century this started changing and the Croatian name appears in sources written in Venice, Rome, and Constantinople, the most important being Constantine Porphyrogenitus' De administrando imperio. The growing interest for Croatia and the Croats can be explained with the events related to the Croatian-Bulgarian conflict, which was a result of the Byzantine war against Simeon. It seems that in order to attract the Croats to his side, Byzantium granted the Croatian ruler with the right to govern Dalmatian cities which were under nominal Byzantine sovereignty. The importance Croats achieved at that time was a result of their military strength, reflected in the exaggerated numbers of Croatian soldiers reported by Constantine. After a long period of instability in the second half of the ninth century, it seems that by the end of the century the dynasty of Trpimir finally managed to appropriate the throne for itself. This enabled the Croats to take an active role in the wars on the Balkans. A new dimension in the relations between Croats and Byzantium was reached most probably after 968, when Svjatoslav occupied Bulgaria and endangered the Empire, while at the same time Byzantium faced difficulties in southern Italy. John I Tzimiskes decided to secure the loyalty of the Croats by sending a crown to their ruler, making him King of Croatia and Dalmatia, but also an eparch, clearly showing the latter's dependant position. The relation between the emperor and the king was made clear by the treatment of Krešimir III and Gojslav by Basil II who forced them to recognize his sovereignty.

Keywords: Croats, Byzantium, Dalmatia, Bulgars, Simeon, Constantine VII, John I Tzimiskes, Tomislav, Stephen I. Držislav, Croatian rulers 